\title{
PERBANDINGAN EFEKTIVITAS DAYA HAMBAT PEMBENTUKAN PLAK PADA BERBAGAI PASTA GIGI YANG TERSEDIA DI KOTA MEDAN
}

\author{
Herlinawati ${ }^{1}$ Aminah br. Saragi ${ }^{2}$, Yetti Lusiani ${ }^{3}$ \\ Poltekkes Kemenkes Medan \\ Email: ${ }^{1}$ drg.erlidaulay@yahoo.com
}

\begin{abstract}
Abstrak
Pengendalian pembentukan plak merupakan tindakan yang penting dilakukan untuk mencegah terjadinya karies gigi dan penyakit periodontal maupun dalam proses perawatan dan penyembuhan penyakit tersebut. Cara yang banyak dilakukan oleh masyarakat untuk menghilangkan plak adalah dengan menyikat gigi menggunakan pasta gigi. Banyak merek pasta gigi dengan perbedaan komposisi dari tiap pasta yang dijual di kota Medan. Adapun tujuan dari penelitian adalah untuk mengetahui perbandingan efektifitas daya hambat pembentukan plak pada berbagai pasta gigi yang tersedia di kota Medan.

Jenis penelitian yang digunakan adalah penelitian eksperimen kuasi dengan rancangan post-test only non equivalent control group design, populasi pada penelitian ini adalah seluruh mahasiswa Jurusan Keperawatan Gigi dengan jumlah 278 orang sedangkan sampelnya ditentukan secara purposive sampling yang memenuhi kriteria inklusi yaitu sebanyak 150 orang. Data primer yang diambil oleh peneliti adalah indeks plak pada masing-masing pasta gigi setelah melakukan sikat gigi dengan pemeriksaan setelah 10 menit, 30 menit, 60 menit, 4 jam, 8 jam. Analisis data dilakukan dengan univariat untuk melihat gambaran pada variabel dan untuk melihat efektivitas daya hambat pembentukan plak dari berbagai pasta gigi digunakan uji anova.

Hasil penelitian menunjukkan indeks plak sesudah menyikat gigi 10 menit pada pasta A, B, C, dan D serta tanpa pasta tidak menunjukkan perbedaan yang signifikan atau nilai $(p=>0.05)$. Pada menit ke 30 sesudah menyikat gigi indeks plak antara pasta A dan pasta B menunjukkan ada perbedaan yang singnifikan $(p=<0.05)$, demikian juga pasta A dengan pasta $\mathrm{D}$ dan pasta $\mathrm{C}$ dengan $\mathrm{D}$ menunjukkan adanya perbedaan yang signifikan $(p=<0.05)$. Sedangkan pada 1 jam setelah menyikat gigi antara pasta $\mathrm{A}$ dan pasta $\mathrm{C}$ ada perbedaan yang signifikan $(p=<0.05)$, akan tetapi pada 4 jam setelah menyikat gigi dan 8 jam setelah menyikat gigi tidak ada perbedaan yang signifikan antara pasta $\mathrm{A}$, pasta $\mathrm{B}$, pasta $\mathrm{C}$ dan pasta $\mathrm{D}$ serta tanpa memakai pasta.

Pasta gigi merupakan bahan untuk membersihkan gigi, yang paling utama adalah teknik menyikat gigi yang baik dan benar dengan menyikat gigi pada seluruh permukaan gigi dan cara yang benar untuk setiap segmen yang ada di rongga mulut.
\end{abstract}

Kata Kunci : Plak, Pasta gigi

\section{Pendahuluan}

Kesehatan gigi dan mulut penting bagi kesehatan dan kesejahteraan tubuh secara umum dan sangat memengaruhi kualitas kehidupan, termasuk fungsi bicara, pengunyahan, dan rasa percaya diri. Gangguan kesehatan gigi dan mulut akan berdampak pada kinerja seseorang. Di Indonesia penyakit gigi dan mulut terutama karies dan penyakit periodontal masih banyak diderita, baik oleh anak-anak maupun usia dewasa. Sebagian besar masalah kesehatan gigi dan mulut sebenarnya dapat dicegah. Banyak cara untuk dapat mengurangi dan mencegah penyakit gigi dan mulut dengan berbagai pendekatan yang meliputi pencegahan yang dimulai pada masyarakat, perawatan oleh diri sendiri dan perawatan secara professional (Putri M. H., Eliza H., Neneng N., 2013).

Menurut Undang-Undang Kesehatan No.36 Tahun 2009 Pasal 93 ayat 1 dan 2 yaitu pelayanan kesehatan gigi dan mulut dilakukan untuk memelihara dan meningkatkan derajat kesehatan masyarakat yang dapat dilakukan dengan tindakan pencegahan penyakit gigi, serta pemulihan kesehatan gigi yang dilaksanakan oleh pemerintah setempat dan dapat juga di lakukan melalui pelayanan kesehatan gigi perorangan, sekolah dan 
masyarakat. Berdasarkan hasil Riset Kesehatan Dasar (2013), prevalensi nasional masalah gigi dan mulut mencapai 25,9 persen, sebanyak 14 provinsi mempunyai prevalensi masalah gigi dan mulut di atas angka nasional. Prevalensi nasional menyikat gigi setiap hari adalah 94,2 persen sebanyak 15 provinsi berada di bawah prevalensi nasional.

Pencegahan dapat didefinisikan sebagai mencegah timbulnya maupun berkembangnya suatu penyakit atau memulihkan fungsi tubuh yang menjadi hilang atau berkurang akibat penyakit. Pencegahan dapat dibagi menurut tingkatan penyakit dan dikelompokkan menjadi pencegahan primer, sekunder, dan tersier. Pencegahan primer adalah mencegah seseorang terkena suatu penyakit, di bidang kedokteran gigi dapat berupa anjuran diet dan kontrol plak. Plak adalah suatu lapisan lunak yang terdiri atas kumpulan mikroorganisme yang berkembang biak di atas suatu matriks yang terbentuk dan melekat erat pada permukaan gigi yang tidak dibersihkan (Pintauli S, Hamada T, 2008).

Salah satu penyebab terjadinya karies gigi dan peradangan pada jaringan periodontal adalah mikroorganisme yang terkandung di dalam plak yang menempel pada permukaan gigi. Plak gigi adalah deposit lunak yang membentuk biofilm dan melekat pada permukaan gigi atau permukaan jaringan keras lain di dalam mulut. Plak gigi terdiri dari massa yang tersusun dari berbagai macam mikro organisme, protein saliva dan sel epitel yang terdeskuamasi. Mikroorganisme yang berperan dalam pembentukan plak gigi adalah bakteri yang mampu membentuk polisakarida ekstrasel dari genus streptococcus, yang didominasi oleh streptococcus mutans. Bakteri ini merupakan flora normal dalam rongga mulut dan dapat berubah menjadi patogen apabila terjadi peningkatan jumlah koloni yang berlebihan, sehingga pertumbuhannya harus dihambat agar tidak menjadi patogen. Plak gigi selain menyebabkan masalah di rongga mulut, dapat juga mengganggu penampilan seseorang. Pembentukan plak gigi bermula dari adanya pelikel yang merupakan lapisan aseluler berprotein yang melapisi gigi, terdiri dari salivary glycoproteins, phosphoproteins, lemak, komponen dari gingival crevicular fluid, sisa dinding sel bakteri yang mati, dan produk hasil mikroba lain. Komposisi pelikel tersebut berperan penting dalam menentukan komposisi mikroflora awal (Carranza FA Jr, 1996).

Karies gigi adalah penyakit multifaktor yang merupakan hasil kombinasi dari 4 (empat) faktor utama yaitu host (gigi), substrat, mikroorganisme di dalam plak dan waktu (Samaranayake, 2002). Plak gigi memegang peranan penting dalam menyebabkan terjadinya karies. Karies gigi merupakan suatu penyakit yang disebabkan oleh adanya interaksi plak kuman dengan diet dan gigi. Tidak diragukan lagi bahwa tanpa adanya plak maka tidak akan timbul karies. Akibatnya salah satu cara pencegahan karies adalah dengan mengusahakan agar pembentukan plak pada permukaan gigi dapat dibatasi, baik dengan cara mencegah pembentukannya atau dengan pembersihan plak dalam jangka waktu tertentu. Usahausaha penelitian untuk pengendalian plak umumnya mengikuti : cara mekanis, cara kemis untuk menghambat pembentukan plak atau menghindari kuman spesifik dan produknya dalam plak.

Hal penting dalam menjaga kebersihan gigi dan mulut adalah kesadaran dalam perilaku pemeliharaan diri masing-masing individu. Pemeliharaan kesehatan gigi dan mulut tersebut sangat erat kaitannya dengan kontrol plak atau menghilangkan plak secara teratur. Secara umum plak gigi merupakan salah satu faktor yang dominan dalam perkembangan suatu karies (Putri M. H., Eliza H., Neneng N., 2013).

Pasta gigi merupakan jenis pasta yang digunakan untuk membersihkan gigi, biasa digunakan dengan sikat gigi. Di Indonesia pasta gigi sering disebut odol. Sebenarnya odol merupakan salah satu merek pasta gigi asal Jerman yang dibawa oleh para tentera Hindia Belanda. Walaupun merek ini sudah berpuluh tahun tidak beredar lagi di Indonesia, akhirnya nama odol telah menjadi nama generik untuk pasta gigi. Hampir semua pasta gigi mengandung lebih dari satu bahan aktif dan hampir semua dipromosikan dengan beberapa keuntungan bagi pengguna. Umumnya pasta gigi yang beredar di pasaran merupakan kombinasi dari bahan abrasive, deterjen dan atau lebih bahan terapeutik. Adapun komposisi dari pasta gigi yaitu: bahan abrasive, air, humectants, surfectan, bahan penambah rasa, bahan terapeutik (Midd M, Cooksy MW, 2016). 
Sehari-hari, kita dihadapkan dengan berbagai macam pilihan pasta gigi. Produsen menawarkan pasta yang dapat mengatasi karang gigi (tartar), atau butuh pasta gigi yang mengandung fluoride, maupun keduanya. Kemudian ada lagi pasta gigi pemutih atau pasta gigi dengan formula bahan-bahan alami.

Dari hasil tanya jawab 55 orang pada masyarakat kota Medan sekitar 65\% menggunakan pasta pepsodent, $15 \%$ memakai pasta formula, $15 \%$ sensodyne dan 5\% closeup. Pasien sering menanyakan tentang pasta gigi mana yang paling baik digunakan untuk menghambat plak. Berdasarkan hal tersebut, dibutuhkan adanya data dan informasi bagi masyarakat tentang pasta gigi yang paling efektif untuk menghambat plak. Selanjutnya perlu dilakukan penelitian bagaimana perbandingan efektivitas daya hambat pembentukan plak pada berbagai pasta gigi yang tersedia di Kota Medan.

\section{Manfaat Penelitian}

Manfaat praktis penelitian ini adalah sebagai informasi mendasar mengenai pasta gigi bagi masyarakat dan untuk dapat mengetahui efektifitas daya hambat pembentukan plak pada berbagai jenis pasta gigi yang tersedia di kota Medan sehingga dapat memilih/menentukan pasta gigi mana sebaiknya digunakan.

Manfaat akademis penelitian ini adalah sebagai informasi dalam bidang pencegahan penyakit gigi (tindakan preventive) tentang pasta gigi yang paling baik daya hambatnya terhadap pembentukan plak.

\section{METODE}

\section{Jenis dan Desain Penelitian}

Jenis penelitian yang digunakan adalah eksperimen kuasi dengan rancangan posttest only non equivalent control group design (pasca intervensi dengan kelompok kontrol), yang terdiri dari 5 kelompok yaitu kelompok yang memakai pasta $\mathrm{A}$, pasta $\mathrm{B}$, pasta $\mathrm{C}$, pasta $\mathrm{D}$, tanpa pasta gigi (kontrol).

Lokasi yang diambil dalam penelitian ini di Jurusan Keperawatan Gigi Poltekkes Kemenkes RI Medan.

Populasi pada penelitian ini adalah seluruh mahasiswa reguler Jurusan Keperawatan Gigi Poltekkes Medan dengan jumlah 278 orang.
Sampel pada penelitian ini berjumlah 150 orang dengan rincian masing-masing kelompok 30 orang. Sampel ditentukan secara purposive sampling dengan kriteria inklusi sebagai berikut :

a. Mahasiswa tk. I dan II dan III Jurusan Keperawatan Gigi Poltekkes Kemenkes RI Medan.

b. Bersedia puasa selama pelaksanaan penelitian (saat intervensi).

\section{Metode Pengumpulan Data}

Dalam penelitian ini data yang dikumpulkan adalah data primer dan data sekunder. Data primer yang diambil oleh peneliti adalah data skor plak setelah melakukan sikat gigi dengan memakai odol yang telah ditentukan setelah 10 menit, 30 menit, 60 menit 4 jam dan 8 jam. Data primer dikumpulkan melalui pengukuran langsung dan mengisi format pemeriksaan.

Teknik pengambilan data :

1. Disclosing solution dioleskan keseluruh permukaan gigi responden.

2. Responden menyikat gigi dengan pasta A, B, C, D, tanpa pasta (kontrol) sampai skor plak "0".

3. Setelah 10 menit, 30 menit, 60 menit dan 4 jam dan 8 jam dioles disclosing solution dan diperiksa skor plak pada responden.

Data sekunder diperoleh dari bagian akademik dan kesiswaan Jurusan Keperawatan gigi Poltekkes Medan.

\section{Teknik Pengolahan dan Analisis Data}

Data yang telah diperoleh dianalisa melalui proses pengolahan data yang mencakup kegiatan sebagai berikut :

1. Editing (Memeriksa), penyuntingan data yang dilakukan untuk menghindari kesalahan atau kemungkinan adanya kuesioner yang belum terisi.

2. Coding (Pengkodean)

Memberikan kode dan skoring terhadap pertanyaan-pertanyaan yang telah diajukan, untuk mempermudah proses entry data.

3. Entry Data, memasukkan data ke komputer dengan menggunakan program SPSS.

4. Cleaning Data, sebelum analisis data dilakukan pengecekan dan perbaikan data yang sudah masuk.

\section{Analisis Data}

Analisis data dilakukan dengan : 
1. Analisis data univariat, untuk melihat gambaran dan karakteristik setiap variabel independen (bebas) serta variabel dependen (terikat).

2. Analisis data untuk melihat perbedaan efektivitas antara pasta A, B, C, D dan sebagai kontrol digunakan uji anova.

\section{Hasil}

\section{Deskripsi Lokasi Penelitian}

Penelitian dilaksanakan di Jurusan Keperawatan Gigi (JKG) Politeknik Kesehatan Kemenkes Medan dengan alamat Jl. Jamin Ginting KM.13,5 Kel. Lau Cih Medan Tuntungan. Jurusan Keperawatan Gigi merupakan salah satu dari tujuh Jurusan yang ada di Poltekkes Medan dengan jumlah mahasiswa tingkat I: 99 orang, tingkat II: 92 dan tingkat III: 87 orang.

\subsubsection{Karakteristik responden}

Responden yang disertakan/dilibatkan pada penelitian ini adalah 150 orang dan sesuai dengan kriteria inklusi. Distribusi responden berdasarkan umur dapat dilihat pada grafik yang tertera di bawah ini:

\section{UMUR}

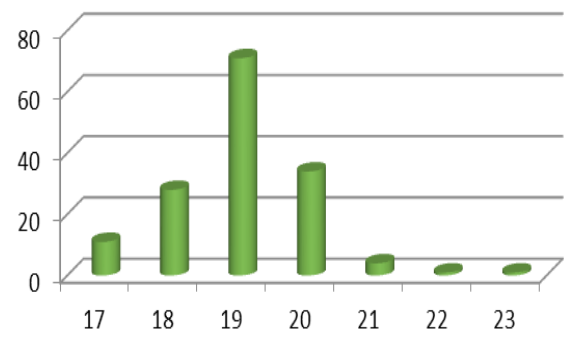

FREKUENS

\section{Gambar 5.1. Grafik Persentase}

Berdasarkan Umur Responden

Grafik di atas menunjukkan umur 17 tahun sebanyak 11 orang $(7,3 \%), 18$ tahun yakni 28 orang $(18,7 \%), 19$ tahun sebanyak 71 orang $(47,3 \%)$, umur 20 tahun sebanyak 34 orang $(22,7 \%)$, umur 21 yaitu 4 orang $(2,7 \%)$ sedangkan umur 22 dan 23 masing-masing 1 orang $(0,7 \%)$. Distribusi Umur pasien berdasarkan kelompok responden dapat dilihat dari tabel di bawah ini:

Tabel 5.1. Distribusi Frekuensi Berdasarkan Umur Pada Kelompok Responden Yang Menggunakan Pasta A, B, C, D dan Tanpa Pasta

\begin{tabular}{llllll}
\hline $\begin{array}{l}\text { Umur } \\
\text { (tahun) }\end{array}$ & A & PASTA & C & D & Panpa \\
\hline 17 & 1 & 2 & 8 & - & - \\
18 & 2 & 2 & 12 & 8 & 4
\end{tabular}

\begin{tabular}{llllll}
19 & 19 & 15 & 8 & 18 & 11 \\
20 & 8 & 10 & 1 & 4 & 11 \\
21 & & & & & 4 \\
22 & & & 1 & & \\
23 & & 1 & & & \\
\hline Total & 30 & 30 & 30 & 30 & 30 \\
\hline
\end{tabular}

Dari tabel 5.1 menunjukkan pada kelompok yang menggunakan pasta A yang berumur 17 tahun 1 orang, 18 tahun 2 orang, 19 tahun 19 orang, dan 20 tahun 8 orang. Kelompok yang menggunakan pasta $\mathrm{B}$ yang berumur 17 tahun 2 orang, 18 tahun 2 orang, 19 tahun 15 orang, dan 20 tahun 10 orang dan 23 tahun 1 orang. Kelompok yang menggunakan pasta $\mathrm{C}$ yang berumur 17 tahun 8 orang, 18 tahun 12 orang, 19 tahun 8 orang, dan 20 tahun 1 orang dan 22 tahun 1 orang. Kelompok yang menggunakan pasta D yang berumur 17 tahun tidak ditemukan, 18 tahun 8 orang, 19 tahun 18 orang, dan 20 tahun 4 orang dan 23 tahun 1 orang. Kelompok yang tidak menggunakan pasta yang berumur 17 tahun 2 orang, 18 tahun 2 orang, 19 tahun 15 orang, dan 20 tahun 10 orang dan 23 tahun 1 orang.

Distribusi responden berdasarkan jenis kelamin dapat dilihat pada grafik di bawah ini: Distribusi responden berdasarkan jenis kelamin pada kelompok dapat dilihat dari tabel di bawah ini :

Tabel 5.2. Distribusi Frekuensi Berdasarkan jenis kelamin Pada Kelompok Responden Yang Menggunakan Pasta A, B, C, D dan Tanpa Pasta

\begin{tabular}{llllll}
\hline Jenis & \multicolumn{2}{c}{ PASTA } & & Tanpa \\
Kelamin & A & B & C & D & Pasta \\
\hline Laki-laki & 3 & - & - & 2 & 4 \\
Perempuan & 27 & 30 & 30 & 28 & 26 \\
\hline Total & 30 & 30 & 30 & 30 & 30 \\
\hline
\end{tabular}

Dari tabel 5.2. di atas menunjukkan jenis kelamin untuk kelompok pasta A laki-laki berjumlah 3 orang dan perempuan 27 orang. Kelompok pasta B dan kelompok pasta C seluruhnya perempuan. Kelompok pasta D laki-laki 2 orang dan perempuan 28 orang sedangkan kelompok tanpa pasta laki-laki 4 orang dan 26 orang perempuan.

\section{Indeks Plak Pada Responden Yang Menggunakan Pasta A}


Jurnal Ilmiah Pannmed (Pharmacyst, Analyst, Nurse, Nutrition, Midwivery, Environment, Dental Hygiene)

Vol. 15 No.1 Januari - April 2020

Hasil penelitian Indeks Plak pada responden yang menggunakan pasta $\mathrm{A}$ adalah sebagai berikut:

Tabel 5.3. Indeks Plak Rata-Rata Pada Kelompok Yang Menggunakan Pasta A

\begin{tabular}{llllll}
\hline Perlakuan & 10 & 30 & 1 & 4 & 8 \\
& menit & menit & jam & jam & jam \\
\hline Pasta A & 0,017 & 0,325 & 0,346 & 0,889 & 1,357 \\
\hline
\end{tabular}

Dari tabel 5.3 menunjukkan rata-rata indeks plak sesudah 10 menit menyikat gigi dengan pasta $A$ adalah 0,017 , sesudah 30 menit adalah 0,325 , sesudah 1 jam sebesar 0,346, sesudah 4 jam adalah 0,889 dan sesudah 8 jam adalah 1,357 .

\section{Indeks Plak Pada Responden Yang Menggunakan Pasta B}

Hasil penelitian Indeks Plak pada responden yang menggunakan pasta $\mathrm{B}$ adalah sebagai berikut:

Tabel 5.4. Indeks Plak Rata-Rata Pada Kelompok Yang Menggunakan Pasta B

\begin{tabular}{llllll}
\hline Perlakuan & $\begin{array}{l}10 \\
\text { menit }\end{array}$ & $\begin{array}{l}30 \\
\text { menit }\end{array}$ & 1 jam & 4 jam & 8 jam \\
\hline Pasta B & 0,007 & 0,227 & 0,425 & 0,895 & 1,314 \\
\hline
\end{tabular}

Dari tabel 5.4. menunjukkan rata-rata indeks plak sesudah 10 menit menyikat gigi dengan pasta $\mathrm{B}$ adalah 0,007 , sesudah 30 menit adalah 0,227 , sesudah 1 jam sebesar 0,425 , sesudah 4 jam adalah 0,895 dan sesudah 8 jam adalah 1,314 .

Indeks Plak Pada Responden Yang Menggunakan Pasta C

Hasil penelitian Indeks Plak pada responden yang menggunakan pasta $\mathrm{C}$ adalah sebagai berikut:

Tabel 5.5. Indeks Plak Rata-Rata Pada Kelompok Yang Menggunakan Pasta $\mathrm{C}$

\begin{tabular}{llllll}
\hline Perlakuan & 10 & 30 & 1 & 4 & 8 \\
& menit & menit & jam & jam & jam \\
\hline Pasta $\mathrm{C}$ & 0,008 & 0,312 & 0,498 & 1,078 & 1,467 \\
\hline
\end{tabular}

Dari tabel 5.5. menunjukkan rata-rata indeks plak sesudah 10 menit menyikat gigi dengan pasta $\mathrm{C}$ adalah 0,008 , sesudah 30 menit adalah 0,312 sesudah 1 jam sebesar 0,498 , sesudah 4 jam adalah 1,078 dan sesudah 8 jam adalah 1,467.

\section{Indeks Plak Pada Responden Yang Menggunakan Pasta D}

Hasil penelitian Indeks Plak pada responden yang menggunakan pasta $\mathrm{D}$ adalah sebagai berikut:

Tabel 5.6. Indeks Plak Rata-Rata Pada Kelompok Yang Menggunakan Pasta

\section{D}

\begin{tabular}{llllll}
\hline Perlakuan & 10 & 30 & 1 & 4 & 8 \\
& menit & menit & jam & jam & jam \\
\hline Pasta C & 0,016 & 0,212 & 0,386 & 0,937 & 1,311 \\
\hline
\end{tabular}

Dari tabel 5.6. menunjukkan rata-rata indeks plak sesudah 10 menit menyikat gigi dengan pasta $\mathrm{D}$ adalah 0,016 , sesudah 30 menit adalah 0,212, sesudah 1 jam sebesar 0,386 , sesudah 4 jam adalah 0,937 dan sesudah 8 jam adalah 1,311 .

Indeks Plak Pada Responden Yang Menyikat Gigi Tanpa Pasta

Hasil penelitian Indeks Plak pada responden yang meyikat gigi tanpa pasta adalah sebagai berikut:

Tabel 5.7. Indeks Plak Rata-Rata Pada Kelompok Yang Menyikat Gigi Tanpa Pasta

\begin{tabular}{|c|c|c|c|c|c|}
\hline Perlakuan & $\begin{array}{l}10 \\
\text { menit }\end{array}$ & $\begin{array}{l}30 \\
\text { menit }\end{array}$ & $\begin{array}{l}1 \\
\text { jam }\end{array}$ & $\begin{array}{l}4 \\
\text { jam }\end{array}$ & $\begin{array}{l}8 \\
\text { jam }\end{array}$ \\
\hline $\begin{array}{l}\text { Tanpa } \\
\text { Pasta }\end{array}$ & 0,016 & 0,212 & 0,386 & 0,937 & 1,311 \\
\hline
\end{tabular}

Dari tabel 5.7. menunjukkan rata-rata indeks plak sesudah 10 menit menyikat gigi tanpa pasta adalah 0,016, sesudah 30 menit adalah 0,212 , sesudah 1 jam sebesar 0,386 , sesudah 4 jam adalah 0,937 dan sesudah 8 jam adalah 1,311 
Hasil Analisis Nilai Indek Plak Berdasarkan Perbedaan Pasta Gigi Dan Tanpa Pasta gigi

Analisis yang digunakan adalah uji anova one way (anova satu arah) untuk menguji perbandingan rata-rata antara beberapa kelompok data, karena data bersifat numerik dan kategorik. Adapun hasil analisis terlihat pada tabel berikut ini :

Tabel 5.8. Hasil Uji Nilai Indek Plak Berdasarkan Perbedaan Pasta Gigi Dan Tanpa Pasta Gigi (nilai $p$ )

a. Nilai Indeks Plak Setelah 10 Menit

b. Nilai Indeks Plak Setelah 30 Menit

\begin{tabular}{|c|l|l|l|l|l|}
\hline VARIABEL & $\begin{array}{l}\text { TANPA } \\
\text { PASTA }\end{array}$ & \multicolumn{1}{|c|}{ A } & \multicolumn{1}{|c|}{ B } & D \\
\hline $\begin{array}{l}\text { TANPA } \\
\text { PASTA }\end{array}$ & & 0,161 & 0,462 & 0,257 & 0,295 \\
\hline A & 0,161 & & 0,034 & 0,787 & 0,015 \\
\hline B & 0,462 & 0,034 & & 0,063 & 0,754 \\
\hline C & 0,257 & 0,787 & 0.63 & & 0.030 \\
\hline D & 0.295 & 0.015 & 0.754 & 0.030 & \\
\hline
\end{tabular}

c. Nilai Indeks Plak Setelah 1 Jam

\begin{tabular}{|c|l|l|l|l|c|}
\hline VARIABEL & $\begin{array}{l}\text { TANPA } \\
\text { PASTA }\end{array}$ & \multicolumn{1}{|c|}{ A } & C & D \\
\hline $\begin{array}{l}\text { TANPA } \\
\text { PASTA }\end{array}$ & & 0,588 & 0,466 & 0,059 & 0,923 \\
\hline A & 0,588 & & 0,205 & 0,016 & 0,524 \\
\hline B & 0,466 & 0,205 & & 0,243 & 0,527 \\
\hline C & 0,059 & 0,016 & 0,243 & & 0,073 \\
\hline D & 0,923 & 0,524 & 0,527 & 0,073 & \\
\hline
\end{tabular}

d. Nilai Indeks Plak Setelah 4 Jam

\begin{tabular}{|c|l|l|l|l|c|}
\hline VARIABEL & $\begin{array}{l}\text { TANPA } \\
\text { PASTA }\end{array}$ & \multicolumn{1}{|c|}{ A } & C & D \\
\hline $\begin{array}{l}\text { TANPA } \\
\text { PASTA }\end{array}$ & & 0,676 & 0,636 & 0,59 & 0,428 \\
\hline A & 0,676 & & 0,957 & 0,139 & 0,707 \\
\hline B & 0,638 & 0,957 & & 0,154 & 0,747 \\
\hline C & 0,059 & 0,139 & 0,154 & & 0,268 \\
\hline D & 0,694 & 0,916 & 0,258 & 0,935 & \\
\hline
\end{tabular}

e. Nilai Indeks Plak Setelah 8 Jam

\begin{tabular}{|c|l|l|l|l|l|}
\hline VARIABEL & $\begin{array}{l}\text { TANPA } \\
\text { PASTA }\end{array}$ & \multicolumn{1}{|c|}{ A } & B & C & \\
\hline $\begin{array}{c}\text { TANPA } \\
\text { PASTA }\end{array}$ & & 0,694 & 0,916 & 0,258 & 0,935 \\
\hline A & 0,694 & & 0,773 & 0,459 & 0,754 \\
\hline B & 0,916 & 0,773 & & 0,305 & 0,980 \\
\hline C & 0,258 & 0,459 & 0,305 & & 0,293 \\
\hline
\end{tabular}




\begin{tabular}{|l|l|l|l|l|l|}
\hline D & 0,935 & 0,754 & 0,980 & 0,293 & \\
\hline
\end{tabular}

\section{Pembahasan}

Pasta Gigi Yang Paling Efektif Daya Hambatnya Terhadap Pembentukan Plak Pada tabel 5.8. menunjukkan indeks plak sesudah menyikat gigi 10 menit pada pasta A, B, C, dan D serta tanpa pasta tidak menunjukkan perbedaan yang signifikan atau nilai $(p=>0.05)$. Menyikat gigi baru dilakukan pada responden lebih kurang 10 menit, proses pembentukan plak baru akan mulai. Menurut Putri M. H. dkk,(2013), proses pembentukan plak terdiri atas dua tahap. Tahap pertama merupakan tahap pembentukan lapisan acquired pellicle sementara tahap kedua merupakan tahap proliferasi bakteri. Acquired pellicle merupakan lapisan tipis, licin, tidak berwarna, translusen, aseluler, dan bebas bakteri. Pada tahap pertama, setelah acquired pellicle terbentuk, bakteri mulai berproliferasi disertai pembentukan matriks interbakterial yang terdiri atas polisakarida ekstraseluler, yaitu levan dan dextran dan juga mengandung protein saliva.

Pada menit ke 30 sesudah menyikat gigi peneliti menilai lagi indeks plak responden. Pasta A dengan rata-rata 0,325 dan Pasta B dengan rata-rata 0,227 dari nilai indeks plak tersebut menunjukkan pasta $\mathrm{B}$ lebih efektif daya hambatnya terhadap indeks plak dan pasta B menunjukkan ada perbedaan yang singnifikan $(p=<0.05)$ terhadap pasta $\mathrm{A}$, demikian juga pasta $\mathrm{C}$ dengan rata-rata 0,312 dengan pasta $\mathrm{D}$ dengan rata-rata 0,212, pasta D lebih efektif daya hambatnya dari Pasta $\mathrm{C}$ dan pasta $\mathrm{D}$ signifikan $(p=<0.05)$ terhadap pasta $\mathrm{C}$. Pasta D dengan rata-rata 0,212 lebih efektif daya hambatnya terhadap Pasta A dengan rata-rata 0,325 . Komposisi pasta yang terdiri dari: PEG-32, flavor, sodium fluoride $(0,32 \%)$, zinc sulfate, mica, sodium hydroxide, $\mathrm{Cl} 42090, \mathrm{Cl} 47005, \mathrm{Cl}$ 77891 ternyata cukup efektif terhadap indeks plak pada menit ke 30 setelah responden menyikat gigi.

Setelah menyikat gigi, 1 jam kemudian indeks plak responden diukur kembali dan hasilnya menunjukkan pasta A dengan rata-rata 0,346 dan pasta $\mathrm{C}$ dengan rata-rata 0,496 , pasta $\mathrm{A}$ lebih efektif daya hambatnya terhadap indek plaK dibandingkan dengan pasta $\mathrm{C}$ serta ada perbedaan yang signifikan $(p=<0.05$ dengan pasta $C$. Pasta A yang digunakan mengandung : Gliserin, strontium chloride hexahydrate $(10 \%)$, calcium carbonate, silica, hydroxyethyl cellulose, sodium methyl cocoyl taurate, peppermint (Mentha Piperita) oil, Cl 77891, PEG-40 stearate, mathylparaben, propylparaben, Cl 45410 .

Selanjutnya setelah 4 jam responden menyikat gigi nilai indeks plak responden diperiksa kembali dan menunjukkan tidak ada perbedaan yang signifikan antara pasta $\mathrm{A}$, pasta $\mathrm{B}$, pasta $\mathrm{C}$ dan pasta $D$ serta tanpa pasta terhadap nilai indeks plak. Demikian juga setelah 8 jam menyikat gigi nilai indeks plak responden diperiksa kembali dan menunjukkan tidak ada perbedaan yang signifikan antara pasta A, pasta $B$, pasta $C$ dan pasta $D$ serta tanpa pasta.

\section{KESIMPULAN DAN SARAN}

\subsection{Kesimpulan}

Dari hasil penelitian dapat disimpulkan bahwa :

1. Indeks plak sesudah menyikat gigi 10 menit kemudian pada pasta $\mathrm{A}, \mathrm{B}, \mathrm{C}$, dan D serta tanpa pasta tidak menunjukkan perbedaan yang signifikan atau nilai $(p=>0.05)$.

2. Pasta D dengan komposisi yang terdiri dari: PEG-32, flavor, sodium fluoride $(0,32 \%)$, zinc sulfate, mica, sodium hydroxide, $\mathrm{Cl} 42090$, $\mathrm{Cl}$ 47005, Cl 77891 ternyata 
cukup efektif terhadap indeks plak pada menit ke 30 setelah responden menyikat gigi.

3. Sedangkan pada 1 jam setelah menyikat gigi antara pasta A dan pasta $\mathrm{C}$ ada perbedaan yang signifikan ( $p=<0.05$ ). Pasta A yang digunakan mengandung : Gliserin, strontium chloride hexahydrate $(10 \%)$, calcium carbonate, silica, hydroxyethyl cellulose, sodium methyl cocoyl taurate, peppermint (Mentha Piperita) oil, Cl 77891, PEG-40 stearate, mathylparaben, propylparaben, $\mathrm{Cl} 45410$.

4. Pada 4 jam setelah menyikat gigi dan 8 jam setelah menyikat gigi tidak ada perbedaan yang signifikan antara pasta $\mathrm{A}$, pasta $\mathrm{B}$, pasta C dan pasta D serta tanpa memakai pasta $(p=>0.05)$.

\subsection{Saran}

1. Perlu disosialisasikan bahwa pasta gigi merupakan bahan/ alat bantu untuk membersihkan gigi dan yang paling utama adalah teknik menyikat gigi yang baik.

2. Perlu disosialisasikan agar masyarakat bijak dalam menanggapi iklan pasta gigi yang tersedia di pasaran, agar meneliti komposisinya sebelum menjatuhkan pilihan pada suatu produk pasta gigi.

\section{DAFTAR PUSTAKA}

Arikunto S., 2013. Prosedur Penelitian Suatu Pendekatan Praktik. Rineka Cipta.Jakarta.

Azwar, 2013. Metode Penelitian, Pustaka Pelajar Yogyakarta.
Budiarto, E (2002). Biostatistika Untuk Kedokteran dan Kesehatan Masyarakat, EGC, Jakarta.

Carranza FA Jr \& Newman MG (eds), 1996, clinical periodontology, $8^{\text {th }}$ edition, Philadelphia, WB Saunders Co

Daliemunthe S.H., 2006, Terapi Periodontal, Departemen Periodonsia Fakultas Kedokteran Gigi USU, Medan.

2008, Periodonsia, Departemen Periodonsia Fakultas Kedokteran Gigi USU, Medan.

Hastono, S.P, 2001. Modul Analisa Data, Fakultas Kesehatan Masyarakat Universitas Indonesia, Jakarta.

Hidayat R, Tandiari A (2016), Kesehatan Gigi dan Mulut, Apa yang Sebaiknya Anda Tahu, CV, Andi Offset, Yogyakarta.

Hongini S Y, Aditiawarman, M., 2012. Kesehatan Gigi dan Mulut : Pustaka Reka Cipta, Bandung.

Kidd, E.A.M, Bechal S.J (1992), Dasardasar Karies Penyakit dan Penanggulangannya, EGC, Jakarta.

Maarif7sunandrajat.blogspot.co.id, JenisJenis dan Desain Rancangan Penelitian Eksperimen, diakses 19 Desember 2016

Midd M, Cooksy MW. Odol gigi, Diakses 13 Desember 2016

Mount G.J., Hume W.R, (2005), Preservation and Restoration of Tooth Structure,

Australia. 
Nisfiannoor, 2009, Pendekatan Statistika Moderm untuk Ilmu Sosial, Perpustakaan UM, Universitas Negeri Malang.

Notoatmodjo S., 2010. Metodologi Penelitian Kesehatan. Jakarta : Rineka Cipta. , Promosi Kesehatan dan Perilaku Kesehatan, Rineka Cipta, Jakarta

Pintauli, S., Taizo Hamada. (2008). Menuju Gigi dan Mulut Sehat. Medan: USU Press.

Putri M. H., Eliza H., Neneng N., 2013, Ilmu Penyakit Jaringan Keras dan Jaringan Pendukung Gigi, EGC, Jakarta.

Samaranayake LP, MacFarlane TW (eds). 2002. Oral Candidosis. Cambridge : Butterworth \& Co. (Publisher) Ltd.

Sastroasmoro, S., Ismail S., (2011), Dasar-Dasar Metodologi Penelitian Klinis, Sagung Seto, Jakarta.

Sugiyono, (2011) Metode penelitian Kuantitatif kualitatif dan $R \& D$, Alfabeta, Spector, Bandung. 